\title{
Alliances between Israel and Other Nations in Light of the Pentateuch's Prohibitions in the Greek Bible
}

\section{Introduction}

In the second part of the proposed analysis of Greek texts from the Old Testament $^{2}$, it is important to see a difference between the Law of Moses described in Ex 23:22; 34:12; Deut 7:2 and Judg 2:2, and the examples described below. As it turned out, the prohibition of alliance in Exodus and Deuteronomy concerned specifically nations residing in areas devoted to the chosen nation. This is also confirmed by the case of Gibeonites. The examples below describe pacts between nations neighboring with Israel and Abraham, and later on between the rulers of the Northern or Southern Kingdoms. Israelites did not, however, reside in these countries. Therefore, it may be said that the prohibition given by Moses remains intact. How is this prohibition evaluated by the hagiographers? There are several examples where the Old Testament mentions the Greek term diathe $\bar{e} \bar{e}$, a word that is extremely important here. All of these examples are going to be derived from the Septuagint so as to keep a uniform version of the Biblical texts, and consequently attempt to answer the ultimate question - did Judas Maccabeus, the commander of the Maccabean Revolt, break Moses' prohibition by making

\footnotetext{
${ }^{1}$ Rev. Janusz Nawrot, professor - born in 1960 in Międzychód in the Wielkopolskie province. He has been a priest in the Archdiocese of Poznan since 1985. He is also a lecturer at the Faculty of Theology, Adam Mickiewicz University in Poznań. He is a researcher at the Department of Historical Theology. He specializes in exegesis and the theology of the Old Testament; e-mail: jannaw@amu.edu.pl. ORCID 0000-0002-2498-5081.

2 J. Nawrot, Izrael wobec zakazu sprzymierzania się z poganami w wybranych tekstach Septuaginty: część I, "Poznańskie Studia Teologiczne" 34 (2019), pp. 7-28.
} 
a pact with Rome (8:17-32) or not? This will be the subject of the third part of the exegetic triptych, which will be introduced in the present study. ${ }^{3}$

What are concrete examples of signing pacts with one's neighbors? The following fragments will answer this question.

\section{1) Abraham's covenant with Abimelech}

It might seem that Abraham's covenant with Abimelech should not be the subject of the present article as it took place a few ages before God dictated His principles to Moses. From the theological point of view, though, Abraham observed the law without explicitly knowing it because he was an ancestor of the chosen people. One such example can be found in Gen 24:3-4 where an order is given to find Isaac a wife, which goes in line with the later account of Ex 34:16. ${ }^{4}$ It is impossible to imagine that, in light of the prohibition against forming an alliance with the Gentiles, the people's patriarch could act contrary to the Law, later on announced as a norm for the whole people, the descendants of Abraham. It is notable that this historical pact was depicted in a theological way in the Bible. It was done so by the author who was also a member of the religious community in which Abraham was a distinguished member. A proper account can be found in Gen 21:27, which is later repeated in verse $32^{5}$ :

And Abraham took sheep and calves, and gave them to Abimelech, and both made a covenant.

This verse is part of a larger text in vv. 22-34 which describe the act of making a covenant between two sides. Although it is rather impossible to treat the whole account as historical, it can be viewed in etiological terms as alluding to the re-

\footnotetext{
${ }^{3}$ This article is a second part of a bigger whole which will be complemented with a third part. Its research goal will be to answer some of the questions above.

${ }^{4}$ There is a similar theological meaning in the case of Noah's offering after the Flood. The offering was made according to the rules of the upcoming Law in Lev 11:2-22; 20:25; 22:22; Deut 14:3-20 which described the consumption of animals without blemish and their possible offering (i.a. Ex 12:5; 29:1; Lev 1:3,10; Num 29:13-30; Ezek 45:23), J.H. Sailhamer, The Meaning of the Pentateuch: Revelation, Composition and Interpretation, Downers Grove 2009, p. 592; V.P. Hamilton, The Book of Genesis, Chapters 1-17, NICOT, Grand Rapids 1990, pp. 307-308; B.N. Peterson, Genesis as Torah: Reading Narrative as Legal Instruction, Eugene 2018, pp. 68-69.

${ }^{5}$ Unless stated otherwise, all translations come from the English translation of the Septuagint by L.C.L. Brenton, https://www.ellopos.net/elpenor/greek-texts/septuagint/default.asp [accessed 10.05.2020].
} 
lationship between the main protagonist and Beer-sheba. ${ }^{6}$ The literary structure is composed of:

a) the king of Gerar's demand of Abraham (vv. 22-23)

b) Abraham's response (v. 24)

c) Abraham's reproach brought on Abimelech and the king's response (vv. 25-26)

d) making a covenant (v. 27)

e) an etiological ritual of the name Beer-sheba (vv. 28-31)

f) both sides of the covenant leaving (v. 32). ${ }^{7}$

Verse 27 is both Abraham's response to Abimelech's vow to be faithful and honest toward his kin and his land, as well as a result of their quarrel over the well for oxen. This well was taken over by the king's servants from Abraham's cowherds, which the king did not know about (vv. 25-26). The patriarch reciprocates the present from Abimelech (20:14a) with his own gift in the form of sheep and oxen. The gift is also a testimony of validity for their freshly made covenant.

Living in his own times, Abraham abode by the laws which were later given explicitly by Moses (Gen 24:3-4). This fact is in contrast to J. Lemański's commentary - "The patriarch did not know the Law of Moses while making a pact with aliens (Canaanites) (Ex 23:33; Deut 7:2; Lev 20:26)" ${ }^{8}$ If one were to consider the covenant in question from the historical point of view, such a thesis could be easily accepted as Abraham lived a few centuries earlier than Moses. However, if this is merely an etiological narrative, the theology of the whole passage takes precedence before its possible history. This is not to say, however, that the whole story is not historically grounded in the then customs, which the hagiographer clearly cared about. In addition, Abraham (Gen 12:8; 13:4; $21: 33)$ and later Moses (Ex 34:5) remained faithful to God through swearing by the Lord's name, building an altar to the Lord (Gen 12:7-8; 13:18;22:9; and Ex 17:15;20:25;24:4), making an offering with animals without blemish (Gen 15:9, Lev 1:10; 5:15-16; Deut 21:3-9), showing great hospitality to God by cooking with prime ingredients which would later be treated as an offering for the Lord (Gen 18:6; Ex 12:39; Lev 2:1-5), and finally by offering a lamb (Gen 22:7-8; and Lev 5:7; 12:8). ${ }^{9}$

${ }^{6}$ G.W. Coats, Genesis: with an Introduction to Narrative Literature, FOTL 1, Grand Rapids 1983, p. 157.

7 Problems related to the concentric construction of the whole passage, H. Krauss, M. Küchler, Erzählungen der Bibel II: Das Buch Genesis in literarischer Perspektive. Abraham - Isaak - Jakob, Göttingen 2004, p. 93 and J. Cazeaux, Le partage de minuit. Essai sur la Genèse, LD, Paris 2006, pp. 345-350.

8 J. Lemański, Księga Rodzaju, rozdziaty 11,27-36,43. Wstęp - przekład z oryginatu - komentarz, NKB.ST, vol. I/2, Częstochowa 2014, pp. 466-467. Translator's note: The original passage reads "Inna sprawa, że patriarcha zawierając traktat z obcymi (Kananejczycy?) wykazuje się nieznajomością późniejszych przepisów Prawa Mojżeszowego (Wj 23,33; Pwt 7,2; Kpł 20,26)”.

9 The above enumeration was carried out on the basis of terminological similarity. 
This juxtaposition confirms the thesis that Abraham was depicted theologically as a servant completely faithful to God also in what he did, although he could not know the Law from a historical point of view. This same Law of Moses would be obeyed later by his descendants. Hence, there is no need to set covenant laws as a theological background to the relationship between Abraham and Abimelech as the alliance was not of a religious type; it was a secular covenant - or as some exegetes call it - it was a "friendship covenant". ${ }^{10}$ In this particular case, Abraham's faith was not in any way in danger.

\section{2) Solomon's covenant with Hiram}

The fact of signing a treaty can be found in 3 Bas $5: 26^{11}$ :

And the Lord gave wisdom to Solomon as he promised him; and there was peace between Chiram and Solomon, and they made a covenant between them.

This very positive text contains an ending of the closer context of vv. 15-26 where there is an account of political-economic connections of Solomon with Hiram, the king of Tyre. These connections are sealed with a treaty. The above text is written in the Deuteronomistic style. It shows the economic relations between independent countries of the time. There is one end that subjects these entire relations, that is the building of a temple in God's honor by David's son (vv. 17-19). The literary structure of the whole passage is pretty simple:

a) an introduction (v. 15)

b) a description of the exchange of diplomatic notes (vv. 16-20)

c) rejoice of the king of Tyre over the wisdom of the king of Israel (v. 21) $)^{12}$

d) the expectations of the other side of the pact (vv. 22-23)

e) trade exchange between both kingdoms (vv. 24-25).

${ }^{10}$ From a political point of view, R.N. Whybray, Genesis [in:] The Oxford Bible Commentary, ed. by J. Barton, J. Muddiman, Oxford 2001, p. 53; J. Lemański, Księga Rodzaju ..., p. 473.

${ }_{11}$ The abbreviations for the Greek Biblical Books adapted in this article and written in italics are as follows: 1 Bas $=1 \mathrm{Sam} ; 2$ Bas $=2 \mathrm{Sam}, 3$ Bas $=1 \mathrm{Kings}, 4$ Bas $=2 \mathrm{Kings}, 1 \mathrm{Par}=1 \mathrm{Chr}, 2$ $P a r=2 \mathrm{Chr}, 2$ Esdr = Ezr $(2 E s d r 1-10)+\mathrm{Ne}(2 E s d r 11-20), P s=$ The Book of Psalms with the numbering from the Septuagint, Ier $=$ the Book of Jeremiah with the Septuagint's respective division.

12 The fact that a Gentile king preaches respect for the God of Israel is typical of the Deuteronomistic style, which is similar to the speech of Jethro, Moses' father-in-law, to his son-in-law in Ex 18:10. But praising the gods of political partners was typical of the contemporary diplomacy, M.A. Sweeney, I \& II Kings: A Commentary, OTL, Louisville 2013, p. 103. 
Verse 26 is composed of two completely different parts. The first part is strictly theological and it accentuates wisdom as a special gift from the Lord to Solomon (v. 26a). The second part is historical and it presents the sealing of a formal trade pact between both rulers and their kingdoms (v. 26b). ${ }^{13}$

As it can be seen, the agreement between both rulers is an agreement between two equal parties. The economic foundation of this agreement is depicted as a peace covenant which goes in line with the symbolism of Solomon's name his caution in international relations. ${ }^{14}$ It is noteworthy that there is a complete lack of any religious reference in the relations between both kings - they remain in their own faiths. The treaty does not interfere with the prohibition articulated in the Law of Moses. It is, therefore, understandable that foreign people were allowed to co-build the temple in God's honor, which is praised by the author as a token of wisdom on Solomon's part. ${ }^{15}$

\section{3) Asa's covenant with Ben-Hadad I}

The description of the covenant can be found in 3 Bas 15:19, and in 2 Par 16:3, where it is almost identically repeated:

Make a covenant between me and thee, and between my father and thy father:

behold, I have sent thee gold and silver:

come, and turn away from me Baasa king of Israel, and let him depart from me.

The verse above is placed in the closer literary context of vv. 16-21 which give an account of military conflict between Asa, the Judean king, and King Baasha of Israel. This conflict is a legacy of the kings' predecessors - Abijah and Jeroboam I. The structure of the passage is pretty clear:

a) introductory information about a permanent state of war between the kings of Israel and Judah, where the king of Israel had the upper hand (vv. 16$17)^{16}$

13 V. Fritz, 1 \& 2 Kings: A Continental Commentary, Minneapolis 2003, p. 60.

${ }_{14}$ P.R. House, 1,2 Kings: An Exegetical and Theological Exposition of Holy Scripture, NAC 8, Nashville 1995, p. 124.

${ }^{15}$ Contrary to 2 Esdr 4:2-3 when a proposal to co-build a second temple was rejected, J.B. Łach, Księgi 1-2 Królów. Wstęp - przeklad z oryginatu - komentarz-ekskurs (Pismo Święte Starego Testamentu, seria KUL, t. 4, cz. 2), Poznań 2007, p. 183.

${ }^{16}$ The time when the conflict ceased is unknown. The passage of $2 \mathrm{Chr}$ 14:8-15 details the invasion of the so-called Zerah, the Ethiopian under the rule of Asa. However, some researchers claim that the historicity of this event can be questioned, Pierwsza i Druga Ksiegga Kronik, thum., wstęp i komentarz H. Langkammer, (Pismo Święte Starego i Nowego Testamentu w przektadzie 
b) the King of Judah's decision to transfer the treasuries from the temple in Jerusalem to the King of Syria so as to gain military support in the war with the ruler of Israel (v. 18)

c) a proposal to sign a treaty backed up with a gift (v. 19)

d) the King of Syria's decision to change the partner in his alliance and attack on the ruler of Israel (v. 20)

e) the King of Israel's withdrawal from attack on Judah (v. 21).

It is difficult to capture the sense of the first line of v. 3 if one wants to place the call to make a covenant in a specific moment of Asa's rule. It is not known how one should understand the phrase "between my father and your father". It might mean "Let there be an alliance between me and you, like that between my father and your father", which is not verified anywhere in the book. The phrase might therefore mean a continuation of an unwritten pact between the rulers which would secure peace between both kingdoms. Asa suggests a formal pact to Ben-Hadad by bribing him with silver and gold coming from the Lord's temple.

Undoubtedly, the verse above is about a political-military treaty, not a religious one. Yet the author of the Greek text used the same expression as in the prohibitions of the Law of Moses - diatithēmi diathēkēn. The political maneuver of the King of Judah was supposed to weaken the military potential of the Northern neighbor. Thanks to this, it would strengthen the northern border and protect Jerusalem against potential attacks from this or subsequent kings of Israel. ${ }^{17}$ Unquestionably, from the political point of view, this was an advantageous venture for the Judean king, but it was at the expense of depriving the treasury from its valuables which had been placed there at the time of the king's rule (v. 15). The king of Syria listened to his contractor and broke the treaty with the king of Israel by attacking him and destroying the adjacent areas and cities (v. 20). Clearly, both sides of the treaty had their plans with regard to possible military advantages. The Syrian monarch weakened his neighbor, which the Judean king also counted on. He expected to at least temporarily avert danger from Syria which had been enfeebled in the war with Israel. Meanwhile, the author of

z języków oryginalnych), Lublin 2001, p. 265. Meanwhile, the invasion of Zerah, if recognized as true historically, could have happened under the rule of Pharaoh Osorkon I, the son of Shoshenq between 924-889 BC. Conversely, the negative character in this event could have been one of the leaders of the Egyptian army that was stationed near the garrison in Judea or in Gerar, Y. Levin, The Chronicles of the Kings of Judah: 2 Chronicles 10-36: A New Translation and Commentary, London-New York 2017, p. 63. Other academics suppose, on the basis of $2 \mathrm{Chr} 16: 7$, that 885-860 was the time when an unknown seer Hanani prophesied and came to Asa after making a covenant with Ben-Hadad, J.F. Nations, Profits of the Prophets: A Biblical Reference, Bloomington (IN) 2012, p. 13.

${ }_{17}$ P.R. House, 1, 2 Kings..., p. 197. 
the chronicle who noted the prophet Hanani's intervention with the king of Judah made the right theological evaluation of Asa's political steps. The Judean king criticized the prophet for this move (2 Par 16:7-9). The monarch had a hidden motive which was a lack of trust in the Lord and substitute trust in a Gentile man. Hence, the prophet reminded the king of a recent invasion of Zerah the Ethiopian whose army was defeated by the Lord in front of the king when he cried to Him for help (2 Par 14:8-15). Indeed, the monarch needed this trust in the Lord at that time. It was a token of foolishness from the king of Judah who cooperated with a Gentile and simultaneously, rejected God. As a result, he had to fight with the same Syrians whom he had asked for help. ${ }^{18}$ This would be more vivid a century later in the Syro-Ephraimite War in $734 \mathrm{BC}$ when the Lord who guaranteed peace for free ${ }^{19}$ was rejected. Instead, the king of Judah had chosen the earthly Gentile ruler whom he had to pay for an uncertain settlement. All in all, it is important to note that although the Law of Moses is not explicitly mentioned here, the king's action was at odds with the nature of God's relationship with His people. He provides help to the people who put tremendous trust in Him both by the law and through the memory of His interventions for the good of His chosen people.

\section{4) Ahab's covenant with Ben-Hadad II}

The covenant between the kings of Israel and Syria was signed at the end of a series of military events between both kingdoms (3 Bas 21:1-34). Verse 34 reads as follows:

And he made a covenant with him, and let him go.

The entire passage of 3 Bas 21 might be divided into the following parts:

a) Ben-Hadad's invasion of the northern kingdom (v. 1)

b) the King of Syria's diplomatic mission to Ahab and trade between both kings (vv. 2-11)

c) Samaria under siege (v. 12)

d) the Lord's prophecy for Ahab (vv. 13-15)

18 This way the theological truth that human action is not determined in advance is revealed. A human being determines their own destiny in the present time, which has a bearing on their future. God, conversely, might announce this or other consequences of rulers' actions in the sphere of faith on the political or military plane. These consequences should not be treated as His response to the mentioned actions, but as a result of one's own behavior, D.S. Crowther, Prophets \& Prophecies of the Old Testament, Bountiful 1998, p. 89.

${ }_{19}^{19}$ I.a. Lev 26:7-8; Deut 28:7; Ps 89:23 and 1 Sam 7:3,10-11; 2 Sam 22:38-41; Josh 8:22; 2 Chr 20:22-25. 
e) military campaign between both kings and Ben-Hadad's defeat (vv. 16-21)

f) another prophecy mission for Ahab (v. 22)

g) advice from Ben-Hadad (vv. 23-25)

h) another war between both kings and Israelites' victory (vv. 26-30)

i) the king of Syria receiving pardon (vv. 31-34).

The last part of the hagiographer's description presents the winner's attempt to show mercy to the loser and to keep him alive. The scenery where the defeated put sackcloth around their waists and ropes on their heads was supposed to facilitate this (v. 31). Indeed, the invaders had been forgiven (v. 32) and they were allowed to show up in front of the winner (v. 33), as a result of which the loser was freed and a treaty was signed (v. 34). The cost of being freed was the return of the cities that had been seized during the previous campaign ${ }^{20}$ and the permission to trade Israelite goods in Damascus. ${ }^{21}$ King Ahab accepted these proposals and freed Ben-Hadad by making a treaty with him. It is difficult to determine whether the treaty was of a military character, because both adversaries did not probably become allies. ${ }^{22}$ The word diathēke denotes a simple pact between unequal sides, where the winning party gains some goods, and the other part gains peace, above all, after making some concessions. This type of a pact is typical for political treatises signed under coercion as a result of lost combat. ${ }^{23}$ The biblical description stresses Ahab's certain gestures toward the defeated adversary. For one, he is given the right to equality by being allowed to come up into a chariot (v. 33) which for him means public forgiveness. He is also obliged to stay loyal and faithful to the regulations of the treaty and peace after acknowledging Ahab's authority.

The behavior of the king of Israel can only be understood in the context of an unknown prophet's intervention in verse 42 of the same book. He speaks on behalf

${ }^{20}$ Here the issue is about cities conquered as a result of the war described in 1 Kings 15:18-22, although some researchers claim that the list is unknown and that the borders between the countries are different, B. Mazar, Geshur and Maachah, JBL 80 (1961) 1, pp. 16-28.

${ }^{21}$ It is possible that market places had an extraterritorial status, i.e. they were exempt from tax destined for the owner of the land where transactions took place, J.A. Montgomery, H.S. Gehman, A Critical and Exegetical Commentary: The Book of Kings, Edinburgh 1967, p. 325. This is more, however, about the manifestation of Israeli presence on the territory of the defeated enemy, and about control of their loyalty toward the sovereign, V. Fritz, $1 \& 2$ Kings..., p. 207.

22 Some exegetes claim that Ahab counted on a mutual coalition with the Syrian king against the rising power of Assyria. They eventually fought in the Battle of Qarqar under the rule of King Shalmaneser III in 853 BC known for the inscription of the so-called stele of Shalmaneser III, R.D. Patterson, H.J. Austel, 1,2 Kings, (Expositor's Bible Commentary, vol. 4: Kings-Job: with the New International Version of the Holy Bible), Grand Rapids 1988, p. 157.

${ }^{23}$ One example of a disadvantageous agreement for the defeated party is a pact made between the winner Pharaoh Neco and the loser Jehoahaz who was forced to observe all of the orders given by the king of Egypt including dethronement (2 Kings 23:33-34), P.R. House, 1,2 Kings..., pp. 392-393. 
of the Lord and criticizes the decision to spare the Syrian king's life and let him go. The most important thing in understanding the relationship between Ahab and Ben-Hadad is the Hebrew term 'î̌s-hermî, that is "a man of my curse" or "a cursed man", which the Septuagint translated as aner olethrion, that is "a man of death". ${ }^{24}$ The Hebrew etymology is more important here as it contains a term fundamental to the Law of Moses - hèrem which means "a curse" or more specifically an order to destroy all of the adversary's belongings including the adversary himself. Such a situation was also described earlier in Deut 7:2.25 It is however difficult to determine whether hêrem can be applied in this account, because Deut 20:17 speaks that the curse could only be cast on six nations which Arameans or Syrians, as they were described in the Septuagint, did not belong to. Additionally, 1 Sam 15:3 speaks of the same curse herem, this time cast on Amalekites who were subject to complete devastation. This means that the list of nations intended for destruction in Deut 20:17 is not finite or closed. It seems that the right answer lies in 3 Bas 21:13 and 21:28. These both passages include a note about turning in Ben-Hadad's army to Israelites which guaranteed Ahab a two-time victory. This decision by the Lord meant that he should have killed the king of Syria, because such an act would complete the victory over him. Sparing his life meant not only squandering an opportunity to get rid of the enemy, but most of all it meant disobedience to God who guaranteed the said victory. ${ }^{26}$ For this reason the punishment is totally understandable - Ahab would pay his own life for the life of his adversary. Although the agreement between them did not strictly involve the Law of Moses, the Lord reserved the right to punish those who did not act according to His will.

\section{5) Achaz's treaty with Tiglath-Pileser II}

Both passages 4 Bas 16:7-9 and 2 Par 28:16-21 relate to the same event, but it is only the latter which gives its own evaluation of the entire undertaking of the King of Judah - he went to the Assyrian monarch for protection in the war against the Syrian-Israeli coalition of Rezin and Pekah who wanted to dethrone Achaz. This dethronement really took place during the Syro-Ephraimite War in 734-732 BC. ${ }^{27}$ There is a short account in the First Book of Maccabees which was considerably extended and modified in the chronicle tradition. The description includes numerous interventions of the subsequent neighbors of Judah (vv. 17-18), Achaz's battle

${ }^{24}$ This expression could be translated in two ways: in the active mode as the one "who causes death, doom, defeat" or in the passive mode as "a wretched and ill-fated man", A. Bailly, Dictionnaire grec-français, Paris $1963^{26}$, p. 1366.

${ }^{25}$ Also Num 21:2-3; Deut 2:34; 3:6; 13:16,18; 20:17; Josh 2:10, etc.

${ }^{26}$ P.R. House, 1, 2 Kings..., p. 230.

${ }^{27}$ Ibidem, p. 336. 
with Syrians and Israelites (vv. 5-8), and a theological evaluation of these events (v. 19). For the sake of this study, it suffices to quote a part of 4 Bas 16:7-9a:

v. 7: And Achaz sent messengers to Thalgath-phellasar, king of the Assyrians, saying, I am thy servant and thy son:

come up, deliver me out of the hand of the king of Syria, and out of the hand of the king of Israel, who are rising up against me.

v. 8: And Achaz took the silver and the gold that was found

in the treasures of the house of the Lord, and of the king's house, and sent gifts to the king.

v. 9a: And the king of the Assyrians hearkened to him...

The literary construction of this fragment is not problematic whatsoever. The closer context of vv. 5-9 describes:

a) Achaz's defense of Jerusalem against the Israeli-Syrian intervention (vv. 5-6), especially against Elath in the southern part of the country (v. 5)

b) sending messengers to Assyria and asking for intervention with a bribe (vv. 7-8)

c) the emperor's approval to attack the Israeli-Syrian coalition and his campaign aimed at destroying both countries (v. 9a) ${ }^{28}$

First of all, it should be noticed that the text does not include the main grammatical construction diatithèmi diathēkē. Its lack does not, however, determine the proper understanding of the text. It includes a pact or treaty between rulers pursuant to which the Assyrian monarch decided to intervene in an issue which the king of Judea cared about (4 Bas 16:9; 2 Par 28:20). Gold and silver was already a gift in the case of Asa's covenant with Ben-Hadad I. The treaty in question, however, might be treated as a sovereign-vassal agreement, where the latter party is an acting party. There is also a description of gifts which serve to convince one party to enter the treaty. The prophet Isaiah presents a theological evaluation of the king's debate. He advises the king to reach to the Lord for protection as $\mathrm{He}$ is faithful to the covenant with His people to a degree where the king of Judah can ask for a sign for himself and his people in this particular case (Isa 7:1-10). The rejection of the prophet's offer gives rise to one of the most popular messianic prognostications (7:11-16). This does not, however, change the ruler's attitude as he does not have the proper faith and trust in the Lord.

Historical studies show that the words "servant" and "son" are typical for formal liege treatises characteristic of complete loyalty toward the liege..$^{29}$ This type

${ }^{28}$ B.O. Long, 2 Kings, FOTL 10, Grand Rapids 1991, p. 174.

${ }^{29} \mathrm{He}$ is even called a "father", D. McCarthy, Notes on the Love of God in Deuteronomy and the Father-Son Relationship between Yahweh and Israel, CBQ 27 (1965), pp. 144-147. A broader 
of treaty is about complete subjection. And this subjection can be particularly stigmatized because the King of Judah does it of his own free will although he is somewhat forced by the political circumstances. ${ }^{30}$ The obligation to pay rent results from the current circumstances or from the political treaty. ${ }^{31}$ The Greek translator's evaluation of Achaz's actions is crushing. In 2 Par 28:20, the author speaks of Tiglath-pileser coming against (epataksen) Achaz. In the context of the treaty, this coming against was not about the literal expression of combat, but about the outcomes of the king's politics which turned out to be just as hard as the fight between both rulers. However, the expression might also mean that despite the treaty both monarchs did not become political friends and that the Syrian monarch only treated the king of Judah as a subordinate vassal. Verse 21 mentions that despite all the gifts and contributions to the Assyrian monarch, he did not benefit from it at all (ouk eis boètheian autō), most probably because he replaced the war expenses with, equally difficult to him, huge costs incurred due to his dependency on the Assyrian sovereign.

The theological evaluation is unequivocal - Achaz chose the king of Assyria and used the same terminology that the biblical authors used in relations IsraelYahveh - "your son", "your servant" and "to save". ${ }^{32}$ This way Yahveh was consciously and willfully replaced by a human Gentile chosen at the expense of the always faithful Lord. It seems that the political agreement was a religious treason from the king of Judah. One of the religious outcomes of this treason would be weakening of the people's faith. They were accustomed to dissent from the Lord and replaced Him with a human. This way the Greek author of the Septuagint later interpreted the actions of the king of Judah as a rising threat to the faith of the people who were following in the footsteps of their own king.

outline of problem, i.a. W. Moran, The Ancient Near Eastern Background of the Love of God in Deuteronomy, CBQ 25 (1963) 1, pp. 77-87.

30 J.B. Lach, Księgi 1-2 Królów..., p. 492.

${ }^{31}$ I.a. S. Moscati, The Face of the Ancient Orient: Near Eastern Civilization in Pre-classical Times, Mineola 2001, p. 109, 179, 197. Bribery was prohibited in the Torah (Ex 23:8; Deut 16:19), also R.L. Cohn, 2 Kings, (Berit Olam: Studies in Hebrew Narrative \& Poetry, ed. by D.W. Cotter), Collegeville 2000, p. 113. The opinion of H. Tadmor and B. Cogan about the accurate understanding of "bribery" should be supported, Achaz and Tiglath-Pileser in the Book of Kings: Historiographic Considerations, Bib 60 (1979), pp. 499-503. The author of the Septuagint understood the gift of Achaz as political bribery similarly to the earlier use of the term dora in the same context of Asa's bribery toward Ben-Hadad I in 3 Bas 15:19.

${ }^{32}$ The Bible includes hundreds of such expressions in reference to the relations of IsraeliteGod. It is almost impossible to note them all, M.J. De Jong, Isaiah Among the Ancient Near Eastern Prophets: A Comparative Study of the Earliest Stages of the Isaiah Tradition and the Neo-Assyrian Prophecies, Leiden-Boston 2007, pp. 193-202. 


\section{6) A treaty between Judah and Egypt}

The treaty was historically signed at the time of Hezekiah, the king of Judah in 705-701 BC. At that time, hopes were raised when freeing from the firm oppression of the Assyrian empire after the death of Sargon II in 705 BC became possible. Both Egypt and Judah had a vested interest in weakening the empire from the Tigris and the Euphrates as they both knew their own independence was endangered. ${ }^{33}$ Isa 30:1-5 shows a prophetic point of view on the politics of the kingdom of Judah from the 8th cent. BC:

v. 1: Woe to the apostate children, saith the Lord:

ye have framed counsel, not by me, and covenants not by my Spirit, to add sins to sins:

v. 2: [even] they that proceed to go down into Egypt, but they have not enquired of me,

that they might be helped by Pharao, and protected by the Egyptians.

v. 3: For the protection of Pharaoh shall be to you a disgrace, and [there shall be] a reproach to them that trust in Egypt.

v. 4: For there are princes in Tanes, evil messengers.

v. 5: In vain shall they labour [in seeking] to a people, which shall not profit them for help, but [shall be] for a shame and reproach.

The phrase in question - diatithēmi diathēke - does not explicitly appear in the text above. Commentators have no doubt that the treaty between both countries really existed. The criticism from the prophet uttered on behalf of the Lord Himself was primarily directed at the king, then his counselors, and lastly those who undertook the mission to gain Egypt's support in their resistance to the Assyrian monarchy. But was the prophet's attack an accusation against the political activity in general or in this particular case? Some exegetes rightly notice that the lack of action would be a token of deep faith or extreme foolishness from Hezekiah's counselors. ${ }^{34}$ This way the word of God might have served as the foundation for political indifference in dangerous situations and gullible counting on "help from above". It is true that several wins in political-military battles came true because of the power of prayer ${ }^{35}$, but it does not seem to be a normal way of

${ }^{33}$ Details of the historical circumstances of this time, J. Nawrot, Zagłada Asyrii w teofanicznej symbolice ognia: Analiza tekstu Iz 30,27-33, Poznań 2000, pp. 35-36, 37-39.

${ }^{34}$ Statements from other researchers are quoted, among other things, in T. Brzegowy, Ksiega Izajasza. Rozdziaty 13-39, NKB.ST 22/2, Częstochowa 2014, p. 557.

${ }^{35}$ I.a. Ex 17:8-13; 2 Chr 20:14-24. Such an interpretation is also ascribed to e.g. the Battle of Lepanto, the Siege of Jasna Góra during the Swedish invasion of Poland, the Battle of Warsaw or 
acting by politicians responsible for the security of their nations. The making of political-military alliances became a standard for contemporary political leaders. ${ }^{36}$ In the Bible, such relationships were not criticized provided they were destined for the benefit of the chosen nation. Examples include Abraham's covenant with Abimelech or Solomon's covenant with Hiram. For what reason were Isaiah's attempts at Judean-Egyptian coalition attacked then? There are two primary reasons for this:

a) Pharaoh Shebitku's non-invasive politics whereby he was incapable of taking a military initiative in the coalition of countries resisting the Assyrian empire

b) exclusion of God as an authentic guarantor of peace in the Promised Land. ${ }^{37}$

The Judean messengers must have known that relying on weak Egypt would not help to better their situation. The superpower from the Nile could have only supported a coalition of small countries from the region which would act as a buffer before Assyria's attack on their own territory. Egypt did not care about the real welfare of the political agreement with minor and weak kingdoms of Canaan. It only cared about its own safety at the expense of the safety of its coalition partner. Therefore, the biblical author used harsh words of shame and disgrace for the Judeans who set their futile hopes on Egypt (vv. 3-5). But the reproach in vv. 1-2 concerns another cause of the policy of the king of Judah, namely his omitting of the prophet's advice to act accordingly on behalf of the Lord. It would surely be different from the delusion of cooperation with Egypt. This was ultimately proven by God's divine intervention in the defense of Jerusalem in the later stage of the conflict with Assyria (Isa 37:33-35). The ability to make political alliances does not diminish the fact that any society of faith should feel responsible for acknowledging its due role in the social sphere. Faith is not merely an eccentric addition to private life but, following the church's teaching, it is a reality that has a direct impact on social and political life that is founded on moral grounds. It is this important reference that Hezekiah and the bigwigs of Judah lacked. They questioned the covenant and should have remained faithful to its ordinance. The mentioned covenant is no doubt the Sinaitic covenant. It is one of the three most important ones, which obliged its recipients to stay faithful under penalty of cancelling it. ${ }^{38}$ This is visible in the use of terminology related to idolatry, as well as in alliance with Egypt which could have possessed some unknown elements

the retreat of the Red Army from Austria after the Second World War.

${ }^{36}$ O. Kaiser, Isaiah 13-39: A Commentary, OTL, Philadelphia 1974, pp. 286-287.

${ }^{37}$ G.V. Smith, Isaiah 1-39: An Exegetical and Theological Exposition of Holy Scripture, NAC 15A, Nashville 2007, pp. 511-512.

${ }^{38}$ Lev 26:14-15 accentuates this penalty. It combines the theme of insubordination with a breach of the covenant, also Num 15:30-31; 2 Kings 17:15; 2 Chr 36:16; Ezek 16:59; Zech 7:11-13. 
of an idolatrous cult. ${ }^{39}$ Thus, the Lord reacted so harshly, as it was expressed by the prophet's words. According to the later foreboding of Jer 6:19, both the king and his counselors, as well as the whole community picked the fruits of their own decisions by rejecting God's words and His commandments.

\section{7) Zedekiah's covenant with Nebuchadnezzar}

The last but one example of an international treaty is presented in Ezek 17:13. It shows a prophetic evaluation of the last moments of independence in the Kingdom of Judah, right before the destruction of Jerusalem in $587 \mathrm{BC}$. The closer context of vv. 11-18 describes a situation from 598/597 BC when the king of Babylon invaded Judah for the first time and took Jehoiakim captive. He was the last offspring from the House of David and he was taken captive after a threemonth rule, along with his whole family, court, major subjects and educated social classes. He plundered the temple and the king's house, and destroyed the former and the city (4 Bas 24:10-14). ${ }^{40} \mathrm{He}$ appointed his uncle Mattaniah to the throne, and changed his name to Zedekiah who, in his foolishness, rebelled against Nebuchadnezzar (2 Kings 24:17-20). A relevant verse in the Book of Ezekiel reads as follows:

And he shall take of the seed royal, and shall make a covenant with him, and shall bind him with an oath: and he shall take the princes of the land:

The future tense of the whole statement was used in the Greek version of the text to forecast the word that the prophet received and that would show him the near future. Verses 11-18 present God's explanation of the earlier allegory about two eagles and the top of the cedar (vv. 1-10). According to this word (v. 1), the king of Babylon will invade Jerusalem and will take its king and its officials (v. 12). He will appoint another king to the throne, and he will make a covenant with him, and will get the whole weakened country to obey it (v. 14). But the suc-

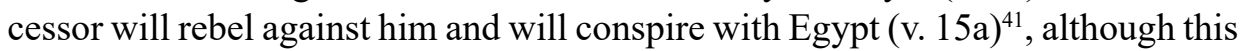
conspiracy will not, according to the will of God, lead to the liberation from the Babylonian authority (v. 15b). The king will be punished and will die in Babylonian exile (v. 16) for breaking the covenant with the Lord. This will happen

39 J. Vermeylen, Du prophète Isaïe à l'apocalyptique: Isaïe I-XXXIV, miroir d'un demi-millénaire d'expérience religieuse en Israël, Paris 1977, pp. 408-410.

40 J. Warzecha, Historia dawnego Izraela, Warszawa 2005, pp. 338-339.

${ }^{41}$ A secret agreement with Pharaoh Hophra was supposed to attract the Egyptian troops and trigger off a war with the Babylonians, A.S. Jasiński, Komentarz do Księgi proroka Ezechiela. Rozdziaty 21-30, OBT 111, Opole 2013, p. 180. 
because the expected help from Egypt will not come, and the angry Babylonian monarch will siege Jerusalem for the second time and will kill its numerous defenders (v. 17). By choosing the pharaoh instead of the Lord, Zedekiah will eventually get expelled and killed, and the country will collapse (v. 18). ${ }^{42}$

The presented context explicitly suggests that there is a treaty imposed by the winner on the defeated whereby Judah becomes completely dependent on Babylon both political- and military-wise. The expression diathèsetai pros auton diathēkēn in v. 13 is limited exclusively to a political treaty and not to a mutual covenant, and does not function on a religious level. There are no signs of the defeated king of Judah being forced to adopt the Gentile faith and to practice idolatry. The fact that the king of Babylon attached a lot of weight to the durability of the pact is strengthened by an oath from the puppet ruler of Judah (eisaksei auton en ara) ${ }^{43}$ This oath was not treated as an addition to the treaty, but more as its fraction. It is important to mention that a ritual agreement was made ${ }^{44}$ after the oath.

The rather correct thesis made by the hagiographer is that Zedekiah's agreement with the pharaoh is at the same time a breach of his covenant with the Lord (vv. 15-16). But why did Zedekiah break his covenant with God by picking the pharaoh, as opposed to the Lord, as the guarantor of the independence of his own country? It seems that he did so much earlier as 4 Bas 24:19-20 stresses his doings as "evil in the Lord's eyes" and presents the rebellion against Nebuchadnezzar as an effect of the Lord's anger at him and Judah. This rebellion is an expression of personal stupidity by Zedekiah, and it is a punishment for the wrong behavior whereby Zedekiah rejected Jeremiah's advice to voluntarily give in to the king of Babylon (Ier 45:17-18). If the God of Israel was summoned now, then Zedekiah also made Him a guarantor of his loyalty toward the Babylonian monarch, which is simply mentioned in 2 Par 36:13. The oath's violation would have meant that Yahveh was a deceitful God that tolerated vile behavior of a subordinate toward the sovereign ${ }^{45}$ This was a primary consequence of the whole agreement that was about to happen; the oath given to the king of Babylon along with the summoning of the Lord both made Him a guarantor of the alleged truthfulness of one's inten-

${ }^{42}$ A more detailed division of the pericope, R.M. Hals, Ezekiel, FOTL 19, Grand Rapids 1989, p. 113.

${ }_{43}$ The Hebrew counterpart 'a $a$ la means a curse that is cast on those who say it and do not keep their word, L.C. Allen, Ezekiel 1-19, WBC 28, Dallas 1994, p. 256.

${ }^{44}$ Through the summoning of gods as witnesses, D.I. Block, The Book of Ezekiel. Chapters 1-24, NICOT, Grand Rapids-Cambridge 1997, p. 542.

${ }^{45}$ L.E. Cooper Sr., Ezekiel: An Exegetical and Theological Exposition of Holy Scripture, NAC 17, Nashville 1994, p. 182. 
tions and the keeping of one's commitments. God's authority was jeopardized, and therefore, Zedekiah would fail in his plans related to Egypt. ${ }^{46}$

\section{8) Jonathan's agreement with Demetrius $I^{47}$}

The last analyzed text can be found in 1 Macc 10:26. It takes the reader to the level of royal diplomacy:

Whereas ye have kept covenants with us, and continued in our friendship, not joining yourselves with our enemies, we have heard hereof, and are glad.

Verses 22-46 in Chapter 10 of the book, unlike the rest, include a trace quantity of historical description which serves as the background in the form of an introduction and an ending to the central content (v. 22,25a; 46,47). The remaining part might be divided into two unequal parts: a monologue from the Seleucid king (vv. 23-24), and a quoted part of the monarch's document directed at Jonathan (vv. 25-45). There are two characters in this passage, but the Seleucid king clearly dominates (vv. 22-45). Conversely, the reaction from Jonathan and the other insurgents is not introduced until vv. 45-46.

In the very beginning of his letter, the monarch underscores the fidelity of those who supported the Hellenization of the country. He does not forget about their favor and wants to reward them for their inconveniences. The joy of Demetrius I, resulting from Jews' alleged obedience to the pact, is supposed to prove that the king respects loyalty and wants to continue to benefit them.

The verb synteree o, that is "I guard, obey, and keep", probably refers to the expectations of the king who would like to be treated according to the principles of loyalty and honesty that a devout Jew would display toward his Lord, following Abraham who respected God's law in its entirety. ${ }^{48}$ However, for Jonathan, as a Jew, the most important tip should be keeping allegiance to the agreement made with a devout man who obeys God's commandments. ${ }^{49}$ This trait is characteristic of a religious man, as opposed to a Gentile, who could exploit any agreement,

46 M. Greenberg, Ezekiel 1-20: A New Translation with Introduction and Commentary, AB 22, Garden City 1983, p. 321.

47 The political agreement between Jonathan and the Gentile ruler was incorporated in this part of the study as it is not included in the scope of the text whose meaning will be given in the third part which will be limited to the covenant with the Roman Empire.

48 Sir 44:20; 41:14; Tob $1: 11 ; 3: 15$.

49 The same term syntēreo can be found in Sir 37:12. 
which could bring the devout Jew another disappointment. ${ }^{50}$ The noun synthēke , that is "an agreement, pact" presupposes a similar warning. In Isa 30:1, the prophet accuses the contemporary decision-makers of forming pacts (synthēkai) with Egypt without God's approval. They will have to pay a pretty penny for this as such negotiations will be harmful and disappointing. ${ }^{51}$ Jonathan is supposed to learn the same lesson in case he makes a pact with Demetrius, who will become equally harmful to him.

Another noun - emmenō - which means “I remain faithful, I don't give up, I am obedient" has a similar tone of warning and incentive. In light of the Israeli law, a man who does not abide by the Lord's commandments and the entire Law expressed in the Torah should be damned. ${ }^{52}$ Since Demetrius tried to fight this Law especially by military means, cooperating with him would be a treason of the Law and it could come under a curse. None of the plans developed without the Lord will endure. ${ }^{53}$ Staying in the coalition with Demetrius would turn out to be as disastrous as the conduct of the inhabitants of Jerusalem who wanted to support their king even though he had long lost God's help described in Jer 21:9. ${ }^{54}$

In the second line of verse 26 , the monarch expresses his joy for receiving a message about the alleged fidelity of the insurgents from the ruling dynasty. The biblical author makes a reference to Lam 1:21 where the writer laments over the stance of the enemies of Israel who rejoice over its collapse. ${ }^{55}$ Similarly, the insurgents' fidelity to the king might turn into joy for him and a chance to collapse for them. All of these biblical references form a strong theological foundation for Jonathan's giving up on Demetrius as an ally. They are also supposed to justify Jonathan in his alliance with Alexander despite the initial letters of the ruling monarch destined for growing the opposition against the Seleucid monarchy.

50 Prov 15:4 convinces of it in its Greek version, La Bible d'Alexandrie: Les Proverbes, vol. 17, trans. and ed. by D.M. d'Hamonville, Paris 2000, pp. 247-248.

51 Similarly to Isa 30:3, J. Nawrot, Zagłada Asyrii..., pp. 37-42.

52 Deut 27:26 sheds some important light on it. In the verse, you can find the expression ouk emmenei, D.L. Christensen, Deuteronomy 21:10-34:12, WBC 6B, Dallas 2002, p. 663.

53 Isa 8:10 contains a similar expression - ou me emmeinē. By contrast, according to the wisdom tradition, those who enemeinen, that is "endured", have His providence, as it is stated in Sir 2:10 and Isa 30:18.

54 P.C. Craigie et al., Jeremiah 1-25, WBC 26, Dallas 1991, p. 289.

55 The same expression èkousan... kai echarēsan, F.B. Huey, Jeremiah - Lamentations: An Exegetical and Theological Exposition of Holy Scripture, NAC 16, Nashville 1993, pp. 457-458. 


\section{Summary}

The conducted exegesis of some particular verses from the Septuagint indicates that two initial covenants made between a representative of the chosen nation with a Gentile party (Abraham and Solomon) did not breach the obligations resulting from the Law of Moses. The theological portrait of Abraham in the Book of Genesis captures an unambiguous evaluation of his conduct in accordance with the Law although the Law itself appeared considerably later when Moses lived. The pact between Solomon and Hiram deserves a similar evaluation. However, the later covenants between the kings of Israel and Judah with Gentile rulers deserve an extremely negative evaluation. Although they did not formally violate the Mosaic prohibitions, they were evaluated as a violation of trust in the Lord as He was the only Partner of the covenant between Himself and the Israelites. Such an interpretation is possible especially in light of Deut 7:6 which accentuates the uniqueness of Israel as a nation chosen by God from among other nations. And because this selection of Israel was done on the foundation of the covenant made on the Mount Sinai, it should be a one-of-a-kind covenant that should not be replaced with another pact signed with a human being, and let alone a Gentile. In all of the cases above, starting from King Asa and ending with Archpriest Jonathan, there was a true violation of the rule whereby the Lord was the only Partner of the covenant with His people. Thus, each of the analyzed treatises met with valid criticism both from a prophet and the inspired author. It is difficult to treat these violations as a major breach of the faith of Israel because of the established diplomatic relations. However, it was the rule of God's uniqueness as a foundation for any sphere in the life of the chosen people that was violated. It included the political sphere which should not be excluded from the chosen people's faith.

\section{Keywords}

Old Testament, Septuagint, the First Book of Maccabees, exegesis, covenants
Abbreviations
$\mathrm{AB} \quad-\quad$ The Anchor Bible
Bib - Biblica
$\mathrm{CBQ}-$ Catholic Biblical Quarterly
FOTL - Forms of the Old Testament Literature
JBL - Journal of Biblical Literature
LD - Lectio Divina
NAC - New American Commentary
NICOT - The New International Commentary on the Old Testament
NKB.ST - Nowy Komentarz Biblijny - Stary Testament
OBT - Opolska Biblioteka Teologiczna
OTL - Old Testament Library
WBC - Word Biblical Commentary 


\section{References}

Allen L.C., Ezekiel 1-19, WBC 28, Dallas 1994.

Bailly A., Dictionnaire grec-français, Paris $1963^{26}$.

Block D.I., The Book of Ezekiel: Chapters 1-24, NICOT, Grand Rapids-Cambridge 1997.

Brzegowy T., Księga Izajasza. Rozdziały 13-39, NKB.ST 22/2, Częstochowa 2014.

Cazeaux J., Le partage de minuit. Essai sur la Genèse, LD, Paris 2006.

Christensen D.L., Deuteronomy 21:10-34:12, WBC 6B, Dallas 2002.

Coats G.W., Genesis: with an Introduction to Narrative Literature, FOTL 1, Grand Rapids 1983.

Cohn R.L., 2 Kings, (Berit Olam: Studies in Hebrew Narrative \& Poetry, ed. by D.W. Cotter), Collegeville 2000.

Cooper L.E., Sr., Ezekiel: An Exegetical and Theological Exposition of Holy Scripture, NAC 17, Nashville 1994.

Craigie P.C. et al., Jeremiah 1-25, WBC 26, Dallas 1991.

Crowther D.S., Prophets \& Prophecies of the Old Testament, Bountiful 1998.

De Jong M.J., Isaiah Among the Ancient Near Eastern Prophets: A Comparative Study of the Earliest Stages of the Isaiah Tradition and the Neo-Assyrian Prophecies, Leiden-Boston 2007.

Fritz V., 1 \& 2 Kings. A Continental Commentary, Minneapolis 2003.

Greenberg M., Ezekiel 1-20: A New Translation with Introduction and Commentary, AB 22, Garden City 1983.

Hals R.M., Ezekiel, FOTL 19, Grand Rapids 1989.

Hamilton V.P., The Book of Genesis, Chapters 1-17, NICOT, Grand Rapids 1990.

House P.R., 1, 2 Kings: An Exegetical and Theological Exposition of Holy Scripture, NAC 8, Nashville 1995.

Huey F.B., Jeremiah - Lamentations: An Exegetical and Theological Exposition of Holy Scripture, NAC 16, Nashville 1993.

Jasiński A.S., Komentarz do Księgi proroka Ezechiela. Rozdziały 21-30, OBT 111, Opole 2013.

Kaiser O., Isaiah 13-39: A Commentary, OTL, Philadelphia 1974.

Krauss H., Küchler M., Erzählungen der Bibel II: Das Buch Genesis in literarischer Perspektive. Abraham - Isaak - Jakob, Göttingen 2004.

La Bible d'Alexandrie: Les Proverbes, vol. 17, trans. and ed. by D.M. d'Hamonville, Paris 2000.

Lemański J., Księga Rodzaju, rozdziały 11,27-36,43. Wstęp - przekład z oryginału komentarz, NKB.ST, vol. I/2, Częstochowa 2014.

Levin Y., The Chronicles of the Kings of Judah: 2 Chronicles 10-36: A New Translation and Commentary, London-New York 2017.

Long B.O., 2 Kings, FOTL 10, Grand Rapids 1991. 
Łach J.B., Księgi 1-2 Królów. Wstęp - przektad z oryginału - komentarz - ekskursy, (Pismo Święte Starego Testamentu, seria KUL, t. 4, cz. 2), Poznań 2007.

Mazar B., Geshur and Maachah, JBL 80 (1961) 1, p. 16-28.

McCarthy D., Notes on the Love of God in Deuteronomy and the Father-Son Relationship between Yahweh and Israel, CBQ 27 (1965), p. 144-147.

Montgomery J.A., Gehman H.S., A Critical and Exegetical Commentary: The Book of Kings, Edinburgh 1967.

Moran W., The Ancient Near Eastern Background of the Love of God in Deuteronomy, CBQ 25 (1963) 1, p. 77-87.

Moscati S., The Face of the Ancient Orient: Near Eastern Civilization in Pre-classical Times, Mineola 2001.

Nations J.F., Profits of the Prophets: A Biblical Reference, Bloomington (IN) 2012.

Nawrot J., Izrael wobec zakazu sprzymierzania się z poganami $w$ wybranych tekstach Septuaginty: część I, „Poznańskie Studia Teologiczne” 34 (2019), p. 7-28.

Nawrot J., Zagłada Asyrii w teofanicznej symbolice ognia: Analiza tekstu Iz 30,27-33, Poznań 2000.

Patterson R.D., Austel H.J., 1,2 Kings, (Expositor's Bible Commentary, vol. 4: KingsJob: with the New International Version of the Holy Bible), Grand Rapids 1988.

Peterson B.N., Genesis as Torah: Reading Narrative as Legal Instruction, Eugene 2018.

Pierwsza i Druga Księga Kronik, thum., wstęp i komentarz H. Langkammer, (Pismo Święte Starego i Nowego Testamentu w przekładzie z języków oryginalnych), Lublin 2001.

Sailhamer J.H., The Meaning of the Pentateuch: Revelation, Composition and Interpretation, Downers Grove 2009.

Smith G.V., Isaiah 1-39: An Exegetical and Theological Exposition of Holy Scripture, NAC 15A, Nashville 2007.

Sweeney M.A., I \& II Kings: A Commentary, OTL, Louisville 2013.

Tadmor H., Cogan B., Achaz and Tiglath-Pileser in the Book of Kings: Historiographic Considerations, Bib 60 (1979), p. 499-503.

Vermeylen J., Du prophète Isaïe à l'apocalyptique: Isaïe I-XXXIV, miroir d'un demimillénaire d'expérience religieuse en Israël, Paris 1977.

Warzecha J., Historia dawnego Izraela, Warszawa 2005.

Whybray R.N., Genesis [in:] The Oxford Bible Commentary, ed. by J. Barton, J. Muddiman, Oxford 2001, p. 38-66. 